\title{
MENINGKATKAN MOTIVASI KEWIRAUSAHAAN MELALUI PENDEKATAN DOMINANSI DALAM PEER LEARNING
}

\author{
Dwi Rorin Mauludin Insana ${ }^{1}$, Yuliana Ambarsari ${ }^{2}$ \\ Program Studi Pendidikan Bahasa Inggris, Universitas Indraprasta PGRI Jakarta ${ }^{1,2}$ \\ Email: dwirorin@gmail.com ${ }^{1}$
}

\begin{abstract}
Abstrak
Suatu kelompok kerja kemungkinan akan berpengaruh banyak dalam pemantapan motivasi mahasiswa untuk pengembangan kewirausahaan. Dalam suatu kelompok kerja, pastinya ada peserta yang dominan atau kurang dominan, dimana anggota yang satu dengan yang lain saling mendukung dan memotivasi untuk keberhasilan hasil akhir kerja kelompok. Hal ini menggugah peneliti untuk mencari tahu apakah efek dalam model dominansi kelompok kerja dapat mendongkrak level motivasi mereka dalam berwirausaha. Penelitian ini bertujuan untuk menganalisis hasil dominansi dengan peer learning terhadap mahasiswa lainnya dalam kelompok kerja dan melihat pengaruh peer learning terhadap motivasi kewirausahaan. Metode penelitian yang digunakan adalah metode kuantitatif eksperimen dengan One group pre test post test dengan sampel sebanyak 60 mahasiswa program studi Pendidikan Bahasa Inggris semester 8. Berdasarkan data hasil penelitian yang disajikan, dapat dilihat secara umum bahwa nilai motivasi kewirausahaan dan pada masing-masing kelompok cenderung meningkat setelah peer learning. Nilai rata-rata pretest adalah 67,1 sedangkan nilai postest adalah 77, kemudian setelah dilakukan uji $\mathrm{t}$ (t-test) diperoleh nilai $t_{\text {hitung, }} 6,967>\mathrm{t}_{\text {tabel, }}, 2,000$, hal ini berarti hipotesis penelitian terdapat pengaruh penggunaan peer learning terhadap motivasi kewirausahaan mahasiswa diterima. Kesimpulan dari penelitian ini adalah terdapat pengaruh signifikan dari peer learning terhadap motivasi berwirausaha mahasiswa dengan peningkatan motivasi terbaik adalah kelompok campuran.
\end{abstract}

Kata Kunci : Tingkat dominansi, motivasi kewirausahaan, peer learning,

\begin{abstract}
A working group is likely to have a large influence on strengthening student motivation for entrepreneurship development. In a work group, there must be participants who are dominant or less dominant, where members from one another support and motivate each other for the success of the final results of group work. It is inspiring for researchers to find out whether the effects in working group dominance models can boost their level of motivation in entrepreneurship. This study aims to analyze the results of dominance by peer learning on other students in the work group and see the effect of peer learning on entrepreneurial motivation. The research method used was a quantitative method of experimentation with One group pre test-post test with a sample of 60 students in the 8th semester of the English Language Education program. Based on the research data presented, it can be seen in general that the values of entrepreneurial motivation and in each group tends to increase after peer learning. The average value of the pretest is 67.1 while the posttest value is 77 , then after the $t$ test ( $t$-test) is obtained the value of $t_{\text {count }}$, 6.967> $t_{\text {table, }}, 2,000$, this means that the research hypothesis has the influence of the use of peer learning on accepted student entrepreneurial motivation. The conclusion of this study is that there is a significant effect of peer learning on the motivation of student entrepreneurship with the best increase in motivation is the mixed group.
\end{abstract}

Keywords: Level of dominance, entrepreneurial motivation, peer learning 


\section{PENDAHULUAN}

Menjadi lulusan sebuah perguruan tingi swasta yang mencetak calon guru terkadang memberikan beban mental tersendiri bagi para mahasiswa. Terkadang beberapa mahasiswa berpendapat bahwa menjadi lulusan pendidikan tidak menjamin mereka harus menjadi tenaga pendidik. Terlebih, mata kuliah kewirausahaan yang diberikan kepada peserta didik cenderung melatih mereka untuk bisa mengembangkan jiwa wirausaha.

Untuk menyikapi mahasiswa Universitas Indraprasta semester akhir yang ingin berdikari dalam membuka peluang wirausaha sesuai keahlian mereka, sangat disarankan untuk mereka bernaung dalam suatu institusi atau grup. Suatu kelompok kerja kemungkinan akan berpengaruh banyak dalam pemantapan motivasi mahasiswa dalam pengembangan kewirausahaan. Dalam suatu kelompok kerja, pastinya ada peserta yang memeliki karakter kepribadian yang dominan atau kurang dominan, dimana anggota yang satu dengan yang lain saling mendukung dan memotivasi untuk keberhasilan hasil akhir kerja kelompok.

Kepribadian adalah salah satu faktor yang berpengaruh terhadap perilaku manusia [1]. Menurut American Psycological Association (APA) bahwa kepribadian merupakan perbedaan individu dalam pola karakteristik berpikir, merasakan, dan berperilaku. Studi tentang kepribadian berfokus pada dua bidang yang luas: Yang pertama adalah memahami perbedaan individu dalam karakteristik kepribadian tertentu, seperti sosiabilitas atau lekas marah. Yang lainnya adalah memahami bagaimana berbagai bagian dari seseorang berkumpul bersama secara keseluruhan [2]. Kepribadian itu terbentuk, dipertahankan, dan mengalami perubahan selama suatu proses sosialisasi berlangsung [3]. Menurut [4] kecerdasan intelektual (IQ) hanya menyumbang $20 \%$ bagi keberhasilan atau kesuksesan, sedangkan $80 \%$ adalah sumbangan faktor lain. Dari hal tersebut dinyatakan bahwa kepribadian seseorang merupakan salah satu faktor yang mempengaruhi keberhasilannya dalam pendidikan. Menurut [5] faktor dalam (faktor bawaan) baik psikis maupun fisik serta faktor luar (faktor lingkungan) seperti musim, adat budaya, dan manusia lain dapat memengaruhi dan turut membentuk kepribadian seseorang. Menurut [6] bahwa kepribadian yang merupakan ekspresi perilaku emosi bisa dikategorikan menjadi 4 tipe perilaku individu ketika berinteraksi dengan lingkungannya yaitu Dominance (D), Influence (I), Steadiness (S), dan Compliance (C). Karakteristik orang tipe D antara lain tegas, ambisius, independen, menyukai persaingan, penerima tantangan, cepat dalam mengambil keputusan, penuntut, tidak sabar, dan tidak menyukai hal yang rutin. Karakteristik orang tipe I antara lain ramah, senang bergaul, suka menghibur orang lain, antusias, optimis, motivator, kurang memerhatikan detail, banyak bicara, mudah lupa, dan seringkali bereaksi berlebihan terhadap sesuatu. Karakteristik orang tipe $\mathrm{S}$ antara lain sabar, gigih, jujur, akomodatif, loyal, tidak terlalu menuntut, ingin menolong orang lain, tidak suka dengan perubahan, kurang antusias, kurang tegas, cenderung menghindar dari konlik, dan sulit menyusun prioritas. Karakteristik orang tipe $\mathrm{C}$ antara lain teliti, terstruktur, berhati-hati dalam membuat keputusan, kritis dalam menganalisa kerja sendiri maupun kerja kelompok, patuh terhadap atasan/pimpinan, kurang fleksibel, defensif ketika dikritik, terlalu mengikuti aturan, dan lamban dalam menyelesaikan tugas karena terlalu memperhatikan detail dan menginginkan kesempurnaan [16]. 


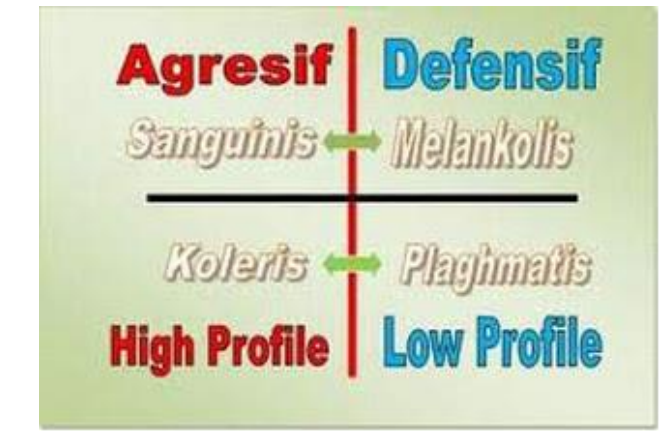

Sumber : http://arie5758.blogspot.com/2011/10/4-kepribadianmanusia-sanguin-koleris.html\#ixzz5VfDy9aVt

\section{Gambar 1. Tipe Kepribadian Manusia}

Menurut [7], peer learning merupakan pembelajaran yang berpusat pada siswa, dalam hal ini siswa belajar dari siswa lain yang memiliki status, umur kematangan/ harga diri yang tidak jauh berbeda dari dirinya sendiri. Metode peer learning menuntut siswa yang mempunyai kemampuan lebih dari temannya dalam pelajaran matematika bertanggung jawab kepada teman-teman kelompoknya untuk mengajarkan suatu materi pelajaran. Pembelajaran dengan temannya sendiri membuat siswa lebih mudah memahami materi pelajaran, karena tidak ada rasa enggan, rendah diri, dan malu jika akan bertanya. Sehingga siswa yang kurang paham tidak segan untuk menanyakan keseulitan-kesulitan yang dihadapinya pada saat belajar. Peer adalah seseorang yang dominan pada suatu kelompok kerja yang berfungsi sebagai pemandu. Biasanya peer mempunyai pengalaman dan kemampuan lebih dalam memotivasi seseorang pembelajar.

Adapun [8] menyatakan bahwa Peer (pemandu) sangat memotivasi terlebih dalam kelas pelajar dewasa, suatu kekuatan atau dukungan akan menular ke pihak lain dengan sangat baik secara horizontal.

Ada dua macam pembelajar dalam suatu kelompok kerja, yaitu pembelajar dominan dan tidak dominan. Pembelajar dominan inilah yang akan menjadi motor penggerak bagi yang lain. Karakter dominan ini sangat diperlukan dalam menggerakan suatu organisasi kerja.

Kemampuan berwirausaha bukan merupakan kemampuan semua orang. Tidak semua orang bisa melakukan proses penawaran, penjualan ataupun marketing maintenance, tetapi demikian kemampuan berwirausaha bisa dipelajari dan dicontohkan. Sehingga dalam berwirausaha perlu ada pelatih atau pendamping yang akan berfungsi sebagai motivator dan mentor.

Ciri wirausaha salah satunya adalah mampu menggerakan orang lain melalui pengaruh dominan yang dimiliki dalam suatu komunitas atau organisasi sehingga orang yang ada di sekitarnya mau mengikuti apa yang diinginkannya [9].

Kewirausahaan adalah suatu proses penerapan kreativitas dan inovasi dalam memecahkan persoalan dan menemukan peluang untuk memperbaiki kehidupan usaha [10]. Berdasarkan konsep tersebut, secara ringkas kewirausahaan dapat didefinisikan sebagai suatu kemampuan kreatif dan inovatif (create new and different) yang dijadikan kiat, dasar, sumberdaya, proses dan perjuangan untuk menciptakan nilai tambah barang dan jasa yang dilakukan dengan keberanian untuk menghadapi risiko.

Karakteristik adalah sifat atau tingkah laku dari seseorang. Oleh sebab itu karakteristik wirausaha dapat diartikan sebagai sifat atau tingkah laku yang khas dari seorang wirausahawan yang membedakannya dari orang lain [11]. Beberapa karakter yang dimilki oleh seorang wirausahawan. antara lain memiliki rasa percaya diri, berorientasi pada tugas dan hasil, berani menanggung resiko, memiliki jiwa kepemimpinan, keorisinalan, berorientasi ke masa depan, jujur dan tekun, memiliki 
kreatifitas tinggi, selalu memiliki komitmen dalam pekerjaan, etos kerja dan tanggung jawab, selalu mencari peluang

Menurut [12] bahwa yang mempengaruhi keputusan seseorang untuk terjun di dunia usaha adalah karena adanya peluang pasar yang cukup besar. Sedangkan menurut [13] beberapa bidang usaha yang bisa dimasuki oleh seseorang untuk menjalankan usahanya diantaranya adalah jasa perorangan dan jasa wisata. Sehingga sangat relevan jika seseorang yang memiliki kemampuan bahasa asing saja atau memiliki kemampuan pendidik dan bahasa Inggris akan dapat memanfaatkan peluang yang cukup bagus ini untuk memasuki bisnis perorangan.

Tujuan penelitian ini adalah untuk mengetahui pengaruh metode 'peer learning' dalam peningkatan motivasi wirausaha mahasiswa yang terbentuk dalam kelompok karakter dominansi.

\section{METODE}

Metode penelitian yang akan digunakan penulis adalah metode eksperimen. Menurut [14], "metode eksperimen adalah metode penelitian yang digunakan untuk mencari pengaruh perlakuan tertentu terhadap yang lain dalam kondisi yang terkendalikan."

Design eksperimen yang digunakan yaitu "One group pre test - post test adalah desain penelitian yang terdapat pre test sebelum diberi perlakuan dan post test setelah perlakuan. Dengan demikian hasil perlakuan dapat diketahui lebih akurat, karena dapat membandingkan dengan keadaan sebelum diberi perlakuan. Penelitian ini merupakan penelitian kuantitatif yang menggunakan one group pre test - post test yang berfokus pada peningkatan hasil motivasi kewirausahaan setelah diberikan perlakuan.
Hipotesis yang diajukan dalam penelitian ini adalah terdapat pengaruh metode peer learning terhadap nilai motivasi kewirausahaan mahasiswa. Adapun sampel yang diambila adalah sebanyak 60 orang dengan pengambilan sampel secara sengaja pada kelas kewirausahaan Program Studi Pendidikan Bahasa Inggris semester 8.

Pengumpulan data untuk karakter dominansi dilakukan dengan menggunakan kuesioner penentu kepribadian [15]. Nantinya akan ada 3 kelompok kerja yaitu, mahasiswa dominan, mahasiswa tidak dominan, dan campuran antara mahasiswa dominan dan tidak dominan. Sedangkan motivasi kewirausahaan diperoleh melalui angket yang berisikan 20 pernyataan berbentuk skala Likert dengan rentangan angka 1 sampai angka 5 untuk pernyataan negatif dan angka 5 sampai angka 1 untuk pernyataan positif [10].

Data yang diperoleh akan dianalisa secara deskriptif hubungan antara nilai dominansi dengan nilai motivasi kewirausahaan. Kemudian diolah secara kuantitatif untuk melihat ukuran pemusatan dan letak seperti mean, modus, median dan simpangan baku, setelah itu dibuat grafik histogram. Selain itu dilakukan uji normalitas dan uji homogenitas. Uji Normalitas dengan mengunakan uji Chi Kuadrat. Uji homogenitas dilakukan pada data nilai pretest dengan nilai postest dengan menggunakan uji Fisher, yaitu dengan membandingkan varians terbesar dengan varians terkecil. Untuk mengetahui adanya pengaruh peer learning terhadap nilai motivasi kewirausahaan mahasiswa. diuji dengan "uji $t$ ( $t=$ test)". Pengujian ini membandingkan antara hasil pre test sebelum diadakannya tindakan (perlakuan) dengan post test sesudah tindakan. dan pengujian hipotesis dilakukan dengan melakukan "uji-t" dengan taraf signifikan sebesar 0,05 dengan ketentuan jika $t_{\text {hitung }}<t_{\text {tabel }}$, maka hipotesis nol (Ho) 
diterima atau tidak terdapat pengaruh, jika $t_{\text {hitung }}>t_{\text {tabel }}$, maka hipotesis nol (Ho) ditolak atau terdapat pengaruh.

\section{HASIL DAN PEMBAHASAN}

Tahap awal dilakukan penilaian angket dominansi yang kemudian dibuatlah kelompok berdasarkan nilai dominansi yaitu, grup dominan (D), grup tidak dominan (ND) dan grup campuran dominan dengan tidak dominan (C). Setelah itu diberikan angket motivasi kewirausahaan. Dari sampel sebanyak 60 orang diambil 7 grup untuk dianalisa secara kualitatif deskriptif. Adapun nilai motivasi kewirausahaan tabel 1 sebagai berikut.

Tabel 1. Nilai Motivasi Kewirausahaan Mahasiswa Bahasa Inggris

\begin{tabular}{ccc}
\hline Grup & \multicolumn{2}{c}{ Motivasi Wirausaha } \\
& Rata-rata Pretest & Rata-rata postest \\
\hline D1 & 66 & 76 \\
D2 & 69 & 78 \\
D3 & 63 & 75 \\
ND1 & 63 & 70 \\
ND2 & 63 & 74 \\
C1 & 66 & 78 \\
C2 & 64 & 75 \\
\hline
\end{tabular}

Tabel 2. Rekap Nilai Motivasi Wirausaha Setiap Grup

\begin{tabular}{ccc}
\hline \multirow{2}{*}{ Grup } & \multicolumn{2}{c}{ Motivasi Wirausaha } \\
& Rata-rata Pretest & Rata-rata postest \\
\hline D & 66 & 76 \\
ND & 63 & 72 \\
C & 65 & 76 \\
\hline
\end{tabular}

Keterangan : Group D = Dominan Group, Group ND = Non dominan Group, Group $\mathrm{C}=$ Mixed Group

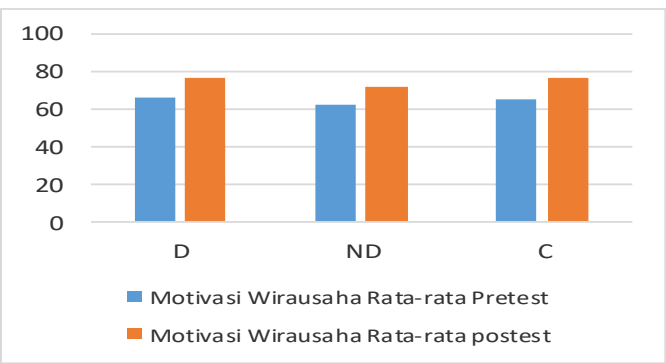

\section{Gambar 3. Grafik nilai motivasi kewirausahaan setiap grup}

Berdasarkan data tersebut di atas bisa dilihat secara umum nilai motivasi kewirausahan dan nilai modul pembelajaran bahasa Inggris setiap grup cenderung meningkat setelah diberikan metode peer learning. Nilai motivasi kewirausahaan grup dominan dan campuran menunjukan nilai yang hampir sama dan lebih tinggi dibandingkan grup non dominan, sedangkan di nilai modul pembelajaran bahasa Inggris grup non dominan mennjukkan nilai lebih tinggi dibandingkan grup dominan dan campuran. Grup campuran bahkan terlihat lebih kecil nilainya dibandingkan grup lainnya. Dapat dilihat bahwa motivasi kewirausahaan grup non dominan lebih rendah dibandingkan grup lainnya. Hal ini menunjukkan bahwa mahasiswa yang memiliki sikap atau kepribadian non dominan lebih cenderung pasif dan introvert. Mereka kurang memiliki sikap mandiri dan lebih suka bekerja sesuai arahan yang ada. Sikap seperti itu memiliki nilai positif pada saat diberikan tugas untuk membuat modul pembelajaran bahasa Inggris. Grup non dominan mendapat nilai yang lebih tinggi dibandingkan grup lainnya. Hal ini ditunjukkan dengan sikap yang siap bekerja sesuai arahan dan selalu mau bekerjasama dalam tim. Sedangkan grup lainnya cenderung individualis dan kurang bisa bekerja dalam tim sehingga kurang memperhatikan proses dan hasil pekerjaan. 
Berdasarkan data yang disajikan, dapat dilihat secara umum bahwa nilai motivasi kewirausahaan pada masing-masing kelompok cenderung meningkat setelah peer-learning. Motivasi kewirausahaan dari kelompok dominan dan kelompok campuran terlihat dalam nilai yang hampir sama tetapi lebih tinggi dari kelompok non dominan,. Sementara dalam pengembangan materi bahasa Inggris, kelompok kelompok non dominan menunjukkan skor yang lebih tinggi daripada kelompok dominan dan kelompok campuran. Kelompok campuran bahkan terlihat lebih kecil nilainya daripada kelompok dominan dan kelompok non dominan.

Menurut hasil perhitungan secara kuantitatif dari data angket motivasi kewirausahaan sebelum perlakuan (pretest) yang berhasil dikumpulkan diperoleh bahwa skor terendah adalah 54, skor tertinggi adalah 80, dan skor rata-rata adalah 67,1. Kemudian nilai median 65,5, nilai modus 63,5standar deviasi 49 dan varians 7 . Hal ini menunjukan rata-rata mahasiswa memiliki nilai motivasi kewirausahaan berada di level menengah atau rata-rata. Bisa dilihat pada gambar 4.

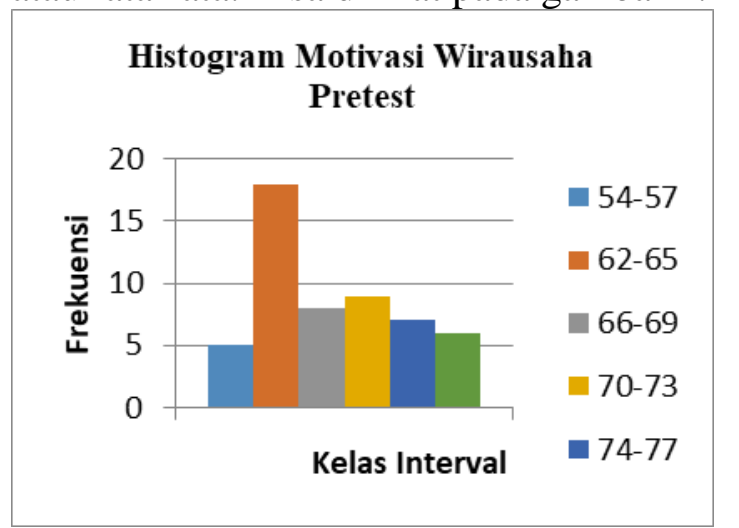

\section{Gambar 4. Histogram Nilai Pretest Motivasi Kewirausahaan}

Sedangkan untuk nilai postest motivasi kewirausahaan diperoleh skor terendah adalah 64, skor tertinggi adalah 90, dan skor rata-rata adalah 77 . Kemudian nilai median 75,5, nilai modus 73,1standar deviasi 45,8 dan varians 6,8. Hal ini menunjukan rata-rata motivasi kewirausahaan cukup baik.

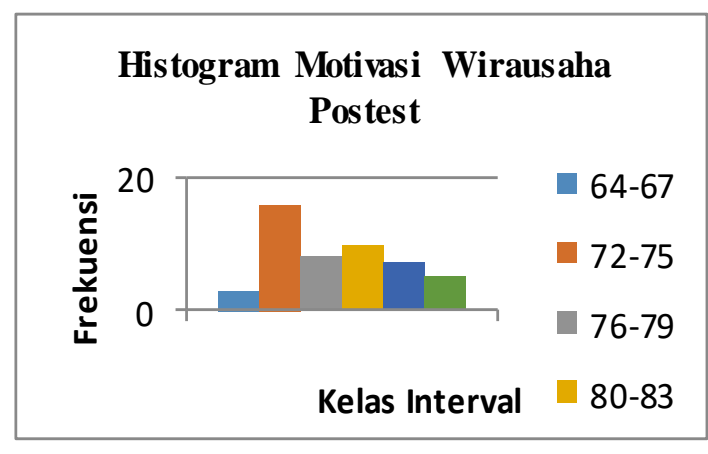

\section{Gambar 5. Histogram Nilai Postest Motivasi Kewirausahaan}

Berdasarkan hasil perhitungan normalitas maka diperoleh nilai $X_{\text {hitung }}=9,64, X_{\text {tabel }}=$ 12,6 , karena $X_{\text {hitung }}{ }^{2}<X_{\text {tabel }}{ }^{2}$ maka Ho diterima, berarti dapat dikatakan bahwa sebaran data berdistribusi normal. Sedang untuk homogenitas diperoleh nilai $F_{\text {hitung }}$ sebesar 1,04 dan $F_{\text {tabel }}$ sebesar 1,61. Sehingga dapat disimpulkan bahwa Fhitung $<$ F table, yaitu $1,04<1,61$, maka $\mathrm{H} 0$ diterima H1 ditolak. Kedua kelompok data memiliki varians yang sama atau homogen. Setelah dilakukan perhitungan dengan Pengujian hipotesis dalam penelitian menggunakan uji $\mathrm{t}$ (t-test) diketahui nilai $t_{\text {hitung }}=6,967$ dan $t_{\text {tabel }}=$ 2,000, maka dapat disimpulkan bahwa $t_{\text {hitung }}>t_{\text {table }}(6,967>2,000)$. Sehingga $\mathrm{H}_{0}$ ditolak, $\mathrm{H}_{1}$ diterima dan thitung bersifat signifikan, yakni terdapat pengaruh penggunaan peer learning terhadap motivasi kewirausahaan mahasiswa.

Hasil yang lebih baik dari kelompok non dominan dan kelompok campuran merupakan hasil dari karakter dasar non dominasi. Hal ini sejalan dengan apa yang dikatakan [17] bahwa orang tidak dominan biasanya orang yang mudah pergi, dapat beradaptasi, semua tujuan yang 
menginginkan di atas segalanya untuk menghindari kontroversi dan konflik.

Ketika [17] menyatakan karakter dominan cenderung emosional dan demonstratif, ini terkadang membawa suasana menyenangkan dalam pembangunan motivasi dari anggota-anggota kelompok dominan. Ini bagus dalam beberapa hal, tetapi, entah bagaimana, itu membawa getaran yang tidak baik dalam kelompok.

Anggota kelompok campuran cenderung memiliki karakter yang berbeda. Ini tidak sesuai dengan upaya terbaik mereka untuk mengembangkan materi, tetapi kombinasi ini membantu mereka menumbuhkan motivasi kewirausahaan mereka. Mereka mengatakan ketika yang dominan lebih banyak bicara, yang tidak dominan mengerti dan mengikuti apa yang diarahkan. Mereka dapat saling mendukung dengan bijak.

Sedangkan [18] menyatakan bahwa tidak ada hasil yang signifikan dari tingkat dominasi terhadap prestasi akademik, hasil penelitian ini menegaskan hal yang sama. Semakin dominan seorang siswa tidak menjamin kesuksesannya; Namun, siswa yang kurang dominan adalah mereka yang hasil akademik lebih baik dari yang lainnya. Tentu saja ini tidak berarti peer learning adalah kelompok kerja terbaik untuk merangsang peserta yang tidak dominan untuk mendapatkan peningkatan yang lebih baik. Jenis pekerjaan kelompok lainnya dapat memberikan hasil yang mungkin lebih baik. Apa yang sudah dilakukan dalam penelitian ini membuktikan bahwa peserta didik dominan kurang bisa membuktikan peningkatan dirinya dalam sebuah pola belajar peer learning untuk peningkatan motivasi kewirausahaan. Kemungkinan peningkatan prestasi mahasiswa dominan juga tidak sebaik mereka yang tidak dominan.

\section{SIMPULAN}

Dari kedua proses perhitungan data secara kualitatif dan kuantitatif, tersebut dapat disimpulkan bahwa Secara keseluruhan, terdapat pengaruh signifikan dari peer learning terhadap motivasi berwirausaha mahasiswa. Adapun kelompok campuran mencapai peningkatan motivasi terbaik.

Saran untuk peneliti lain yang bersifat kewirausahaan adalah untuk melakukan penelitian yang serupa tetapi dengan penekanan gender. Kemungkinan besar terdapat perbedaan antara perempuan dan laki-laki yang dominan daripada yang tidak dominan dalam peran mereka pada peningkatan motivas kewirausahaan.

\section{UCAPAN TERIMA KASIH}

Apresiasi dan terima kasih kepada Direktorat Riset dan Pengabdian Masyarakat, Dirjen Penguatan Riset dan Pengembangan, Kementrian Riset, Teknologi dan Pendidikan Tinggi yang telah membiayai kegiatan Penelitian Dosen Pemula (PDP) Tahun 2018 dengan judul : "Efesiensi Dominansi Mahasiswa dalam Peer Learning untuk Kewirausahaan Berbasis Bahasa Inggris". Terima kasih juga kepada LLDIKTI Wilayah III Jakarta dan Lembaga Penelitian dan Pengabdian Masyarakat Universitas Indraprasta PGRI yang telah membantu kegiatan penelitian ini melalui kontrak penelitian: 032/K3/PNT/2018, Tanggal 6 Maret 2018. Dan Surat Perjanjian / Kontrak Penelitian UNINDRA Nomor 0303/SKP.LT/LPPM/UNINDRA/III/2018, Tanggal 12 Maret 2108

\section{DAFTAR PUSTAKA}

[1] Chaplin JP. Kamus Lengkap Psikologi. Jakarta: Raja Grafindo Persada, 2011.

[2] American Psychological Association (APA). Personality. [retrieved on 3 November 2018]. Available from: http://www.apa.org/topics/personality 
[3] Baharuddin H. Pendidikan \& Psikologi Perkembangan. Jogjakarta: Ar-Ruzz Media, 2012.

[4] Goleman. Emotional Intelligence. Jakarta: Gramedia; 2004

[5] Sujanto A, Lubis H, Hadi T. Psikologi Kepribadian. Jakarta: Bumi Aksara, 2014.

[6] Yanuari A. Personality Assessment Tools For Psychology. Jakarta: One Spirit. 2015.

[7] Wulandari, AP. "Pengaruh Metode Peer Learning dengan Pendekatan Mastery Learning Terhadap Kemampuan Pemahaman Konsep Matematis Siswa MTs Al Hidayah Purwasaba". Skripsi. Universitas Muhammadiyah Purwokerto. Surakarta, 2017.

[8] Syaifullah. "Pengaruh Penerapan Metode Pembelajaran Sebaya (Peer Learning) Terhadap Pembentukan Karakter Cerdas Siswa Jurusan Teknik Pemesinan SMK Negeri 2 Depok Sleman Yogyakarta. MTs Al Hidayah Purwasaba”. Skripsi. Universitas Negeri Yogyakarta. Yogyakarta, 2015.

[9] Kasmir. Kewirausahaan. Jakarta: Rajawali Pers. 2013

[10] Alma, B. Kewirausahaan. Bandung: Alfabeta. 2009.

[11] Insana, DRM dan Mayndarto, EC. "Pembangunan Karakter Wirausaha Mahasiswa Melalui Peningkatan Kualitas Pendidikan Kewirausahaan". Jurnal Ekonomi, vol. 19, no. 3, pp. 349-357, 2017.

[12] Hendro. Dasar-dasar Kewirausahaan. Jakarta: Penerbit Erlangga. 2011.

[13] Mudjiarto dan Wahid, Aliaras. KEWIRAUSAHAAN: Motivasi dan Prestasi dalam karier Wirausaha. Jakarta: Penerbit UIEU-University Press. 2008.

[14] Sugiyono. Metode Penelitian Kuantitatif Kualitatif dan $R \& D$. Bandung: Alfabeta. 2011.
[15] Arie. "Kuesioner Penentu Kepribadian". [Online]. Tersedia: http://arie5758.blogspot.com/2011/ 10/tes-kepribadian-sanguinkoleris.html\#ixzz5A5ZtkZSq [Diakses 1 Oktober 2018]. 2011.

[16] Arie. "Tipe Kepribadian Manusia". [Online]. Tersedia: http://arie5758.blogspot.com/2011/1 0/4-kepribadian-manusia-sanguinkoleris.html\#ixzz5VfDy9aVt [Diakses 1 Oktober 2018]. 2011.

[17] Littauer, F. Personality Plus: How to Understand Yourself by Understanding Others. Michigan: Fleming H.Revell. 2006.

[18] Putri, G.S. "Ahli Tegaskan, Gaya Belajar Tak Pengaruhi Hasil Akademik.". [Online]. Tersedia:https://sains.kompas.com/r ead/2018/04/05/183000623/ahlitegaskan-gaya-belajar-dominantak-pengaruhi-hasil-akademik [Diakses 1 Oktober 2018]. 2018. 